\title{
Vrstniška mediacija
}

Martina Kukovec

\section{Uvod}

\section{Vrstniška mediacija?}

M ediacija je metoda reševanja sporov, $v$ katerem tretja, nevtralna stran (mediator) pomaga dvema ali več sprtim stranem pri razjasnjevanju nesporazuma in iskanju skupne rešitve (Iršič, 2010). Vrstniška mediacija je vrsta mediacija, ki se izvaja v osnovnih in srednjih šolah; izvajajo jo otroci in mladostniki (Haft in Weiss, 1998). Za vrstniško mediacijo usposobljeni učenci (vrstniški mediatorji) rešujejo konflikte med kolegi vrstniki (Haft in Weiss, 1998). Vrstniki, ki so udeleženci mediacije, so medianti. Šole so vrstniško mediacijo vključile v svoj program, saj so pričakovale da se bo zmanjšalo nasilje, izboljšala razredna in šolska klima ter da se bodo vsi učenci naučili pomembnih socialnih veščin (Haft in Weiss, 1998). Upali so, da bo vrstniška mediacija omogočila, da bodo lahko učitelji več poučevali in se manj ukvarjali z disciplino, da se bosta povečali poštenost in morala učencev ter da bodo učenci dobili uvid, kako se da konflikte reševati brez nasilja (Haft in Weiss, 1998). V Sloveniji so se na osnovnih šolah odločili za uporabo vrstniške mediacije zaradi spodbujanja nenasilnega reševanja konfliktov (Rugelj, 20II). Danes je vrstniška mediacija zapisana v vzgojnem načrtu večine osnovnih šol kot preventivna in proaktivna vzgojna dejavnost ter je tako uvrščena v vzgojno-izobraževalni proces za delo z otroki in mladostniki in ni več samo tehnika upravljanja $s$ konflikti (Metelko Lisec, 2008). 


\section{Vrstniški mediator}

Odločitev, da nekdo želi postati vrstniški mediator, mora biti prostovoljna. Učitelji, svetovalni delavci ali sošolci lahko učencu predlagajo, da bi postal vrstniški mediator, vendar je odločitev še vedno njegova (Iršič, 20IO). Harris (2005) je ugotovil, da se mladostniki odločajo za vlogo vrstniškega mediatorja predvsem iz dveh razlogov, in sicer: pomagati drugim vrstnikom in se naučiti veščin za lažje reševanje svojih konfliktov. Tudi rezultati slovenske raziskave kažejo, da se mladi odločajo, da se bodo izučili za vrstniškega mediatorja, da bi pridobili nova znanja in zaradi pomoči vrstnikom (Rugelj, 20ıI). Bodine, Crawford in Schrumpf (2010) menijo, da je lahko vrstniški mediator oseba, ki zna dobro presojati, ki jo vrstniki spoštujejo, in oseba, s katero se vrstniki pogovarjajo in ji tudi zaupajo. Polega tega je pomembno, da ima do določene mere že razvite nekatere socialne veščine (socialni čut, željo po pomoči drugim, empatijo, sodelovalnost in iznajdljivost) in komunikacijske veščine ter da jih je pripravljen nadgrajevati (Prgič, 2oro).

\section{Medvrstniški vpliv}

Spoznanja o medsebojnem vplivu vrstnikov so pripeljala do uvedbe vrstniške mediacije v šole. Mladostniku je družina še zmeraj zelo pomembna in ga nanjo še naprej vežejo zelo trdne vezi. Se pa želi tudi oddaljiti od družine in dokazati, da je sposoben biti samostojen. Pomembne razvojne naloge tega obdobja so vzpostavitev trdnih socialnih vezi, oblikovanje identitete in oblikovanje sistema vrednot ter moralnih načel. Mladostniku vrstniki veliko pomenijo, in tako se pogosto podreja skupinskim normam. Pripadnost skupini se sprva izraža navzven. V zgodnjem mladostništvu preko videza in oblačenja, v srednjem mladostništvu pa se vrstniki poenotijo tudi na področju stališč in norm (Justin in Zupančič, 1991). Odnosi z vrstniki so zelo pomembni za otroke in mladostnike. Želijo biti sprejeti s strani vrstnikov, in to privede do primernih ali manj primernih obnašanj. Vpliv vrstnikov je tako lahko pozitiven ali negativen (Berndt in Keefe, 1995). Vrstniki in vrstniške skupine so lahko nadomestek za starše, saj se z vrstniki lahko več in bolj zaupno pogovarjajo (Harris, 2007). Kot pravijo Haith, Miller in Vasta (1997), vrstniki drug na drugega vplivajo tako, da podkrepijo ali spremenijo vedenje drug drugega. Vrstniki so drug drugemu model, kako se vesti. Odnosi z vrstniki omogočajo posamezniku, da se sooča in uči socialnih veščin, uči se socialnih norm in pravil, sooča se s socialno podporo in pridobiva na samospoštovanju (Hartup, 1992; v Cuijpers, Koot, Van Lier in Witvliet, 2009). 


\section{Medvrstniško nasilje}

Osnovne šole so se odločile za vrstniško mediacijo, da bi spodbujale nenasilno reševanje konfliktov (Rugelj, 20II). Vrstniška mediacija deluje preventivno, saj omogoča, da se konflikti ne razvijejo v vsej svoji meri in ne prerastejo v nasilje (Prgič, 20ıо; Košir, 2013). Medvrstniško nasilje vključuje poleg žrtve in nasilneža še priče medvrstniškega nasilja. Priče lahko s svojim vedenjem do neke mere vplivajo na potek medvrstniškega nasilja. Pri tem je treba poudariti, da se lahko vloge spreminjajo v odvisnosti od situacije. Vrstniki in vrstniška skupina imajo moč, da delujejo preventivno ali pa nasilje spodbujajo. Horne in Orphinas (2006; v Košir, 2013) opazovalce delita na tiste, ki so del problema (podpihujejo, opazujejo, so prestrašeni, jih je sram oziroma se počutijo krive, ker ne pomagajo), in tiste, ki so del rešitve (prosijo za pomoč in pomagajo prepoznati problem). Phye in Sanders (2004; v ibid.) pravita, da opazovalci nimajo naučenih spretnosti, da bi odgovorno in primerno posredovali. Ne vedo, kaj narediti, bojijo se nasilnežev ali jih je strah, da bodo storili kaj narobe. Borghi, Franzoni, Gini in Pozzoli (2008; v ibid.) ugotavljajo, da je vedenje opazovalcev pomemben dejavnik doživljanja občutka varnosti v šoli. Občutek varnosti je višji, če si opazovalci prizadevajo zaščititi žrtev, namesto, da bi spodbujali nasilje ali bili pasivni. Vrstniška mediacija omogoča, da mladostniki izstopijo iz vloge nemega opazovalca medvrstniškega nasilja in z mediacijskimi tehnikami pomagajo vrstnikom, da do medvrstniškega nasilja ne pride, oziroma da znajo odreagirati, ko do njega pride. S tem pa vrstniki sami pripomorejo k zmanjšanju medvrstniškega nasilja in vzpostavijo odnos do medvrstniškega nasilja.

\section{Uporabnost vrstniške mediacije}

Vrstniška mediacija je dopolnitev sedanjim tradicionalnim vzgojnim ukrepom in pristopom v šolah. Vrstniška mediacija je primerna za blažje kršitve, kot so nadlegovanje, zbadanje, opravljanje, nesprejemanje drugačnosti, ustrahovanje, manjši pretepi, manjši vandalizem, prijateljska vprašanja, ljubosumje, razredna nesoglasja, goljufanje in kraja (Berčič, 2008; Cohen, 2012).

\section{Učenje vrstniške mediacije}

Učenci na usposabljanju za vrstniške mediatorje spoznavajo, kaj je konflikt, vrste konfliktov, odzive na konflikt, načela reševanja konfliktov in faze mediacije, učijo se temeljnih mediacijskih tehnik - aktivnega poslušanja, povzemanja, zrcaljenja, preverjanja in postavljanja vprašanj (Bodine et al., 2010; Gilhooley in Scheuch, 2000; Cohen, 2012). Nekateri treningi učence opremijo še z znanji o sprejemanju drugačnosti, o predsodkih, 
razumevanju jeze in pogajanjih (Bodine et al., 20Io). Aktivno poslušanje je temelj mediacije in je pomembno zato, da lahko pravilno razumemo sporočilo in da se izognemo napačni interpretaciji, popačenemu dojemanju situacije ter agresivnemu vedenje obeh oseb (Iršič, 20ıо). Pri aktivnem poslušanju je pomembno, da poslušalec zajame tako besedno sporočilo kot neverbalna sporočila, poslušalec se tako odziva na vsebino kot na način povedanega (Sutton in Steward, 2008; v Košir, 2013). Naloga mediatorja je torej, da posluša tako eno kot drugo stran in tako prispeva $\mathrm{k}$ temu, da udeleženca slišita sama sebe in postopoma slišita tudi drugo stran ter da jasneje izrazita svoje misli (Iršič, 20Io). Aktivni poslušalec ne daje nasvetov in ne sodi, samo posluša in skuša razumeti ter nenehno preverja, ali je prav razumel, kar je slišal (Rogers in Farson, 1987). Program usposabljanja se od šole od šole razlikuje, traja pa v povprečju od 8 do 40 ur (Prgič, 2010).

\section{Učinkovitost ali vpliv vrstniške mediacije}

Vrstniška mediacija predvideva, da so otroci in mladostniki sami zmožni rešiti svoje konflikte. Lawrence (2000; v Baginsky, 2004) pravi, da veliko pridobijo s samostojnim reševanjem konfliktov, saj morajo prevzeti odgovornost za svoja čustva in vedenje Prav tako meni, da otroci pogosto lažje zaupajo vrstnikom kot odraslim. Cohen (20I2) meni, da je vrstniška mediacija učinkovita, ker učenci razumejo svoje vrstnike, saj poznajo vrstniški pritisk, govorico in odnose. Otroci in mladostniki tudi drugače pristopijo h konfliktom kot odrasli, saj se pogovarjajo $\mathrm{z}$ vrstniki na način, ki jim je bližje. Vrstniška mediacija naj bi bila učinkovita tudi zato, ker vrstniški mediatorji nimajo nobene moči nad medianti, medianti mediatorjev namreč ne doživljajo kot avtoritete. Edino, kar mediatorji potrebujejo, je zaupanje in spoštovanje mediantov, da lahko izpeljejo mediacijo (Cohen, 20I2). Mediatorji so lahko tudi vzgled mediantom. Če mediatorji nastopijo spoštljivo, to vrnejo tudi medianti, saj vrstniki potrebujejo medsebojno spoštovanje. K učinkovitosti pa prispeva že sama mediacija kot drugačen način reševanja konfliktov. Vrstniki poročajo, da je dobro, če govorimo o konfliktih, in da je dobro, da jim pri reševanju problema pomaga vrstnik in ne odrasla oseba ter da se ne pogovarja o sankciji, ampak o sporazumu. Harris (2005) je ugotovil, da so vrstniški mediatorji vzor svojim vrstnikom in da se od njih preko opazovanja vodenja mediacijskega postopka veliko naučijo. Ugotovil je tudi, da udeleženci radi sodelujejo v mediaciji, ker lahko komunicirajo z drugimi vrstniki, povedo svojo plat zgodbe, razrešujejo konflikte, so slišani s strani mediatorja in so v varnem ter zaupnem okolju. Učinki se tako kažejo tako na individualni kot šolski ravni, pa tudi širše. Vrstniška mediacija izboljšuje samospoštovanje 
mediatorjev in mediantov, vpliva na medsebojne odnose, naučijo se odgovornosti, zmanjšajo se konflikti, izboljša se šolski uspeh, nadgradijo še socialne veščine, učitelji se lahko bolj posvetijo poučevanju kot discipliniranju in ustvari se okolje, ki omogoča učencem, da se lahko učijo ter varno in konstruktivno socializirajo (Baginsky, 2004). Pomembno je tudi, da vrstniška mediacija deluje preventivno, saj omogoča, da se konflikti ne razvijejo v vsej svoji meri in ne prerastejo v nasilje (Prgič, 20Io). Vrstniška mediacija pripomore $\mathrm{k}$ vzgoji, kjer se otroke vzgaja $\mathrm{k}$ razvijanju sposobnosti aktivnega poslušanja, sodelovanju, sprejemanju drug drugega, dostojanstvu, spoštljivosti, odgovornosti za svoja dejanja in besede, poglabljanju razumevanja, graditvi zaupanja, krepitvi samospoštovanja, samostojnem reševanju konfliktov idr. (ibid.).

\section{Namen raziskave}

Namen raziskave je bil preveriti, kakšni so motivi učencev, ki se odločijo postati vrstniški mediatorji, ter kakšne značilnosti mora imeti vrstniški mediator. Raziskati smo želeli osebnostne značilnosti (empatijo in samospoštovanje) pri učencih, ki so vrstniški mediatorji, in jih primerjati z učenci, ki niso vrstniški mediatorji. Vrstniški mediatorji naj bi za svoje delo potrebovali samospoštovanje (Dolinar, 2006) in empatijo (Prgič, 2006). Zanimali so nas tudi učinki vrstniške mediacije.

\section{Metoda}

Prispevek je nastal na podlagi ugotovitev magistrske naloge Vrstniška mediacija na osnovnih šolah v Mariboru in okolici: značilnosti vrstniških mediatorjev in dosedanje izkušnje $z$ mediacijo. $\mathrm{V}$ pričujočem članku smo poskušali povzeti in predstaviti nekatere ključne ugotovitve raziskave.

\section{Udeleženci}

V raziskavi je sodelovalo 264 učencev rednih osnovnih šol, starih od Io do Is let $(\mathrm{M}=\mathrm{I2} .77 ; \mathrm{SD}=0.9 \mathrm{I})$. Od tega je bilo vključenih $132(50 \%)$ deklet in $132(50 \%)$ fantov. Od 264 vključenih učencev je bilo v raziskavo zajetih 62 vrstniških mediatorjev $(\mathrm{M}=\mathrm{I} 2.66, \mathrm{SD}=\mathrm{I} .04), 19$ (23.5 \%) fantov in $43(76.5 \%)$ deklet. Tako predstavlja 62 vrstniških mediatorjev podvzorec 264 učencev. Devet vrstniških mediatorjev je bilo učencev šestega razreda, I3 učencev sedmega razreda, 25 učencev osmega razreda in is učencev devetega razreda. Udeleženci so bili učenci šestih osnovnih šol. V raziskavi je sodelovalo tudi šest mediatork koodinatork vrstniške mediacije na vključenih osnovnih šolah. 


\section{Pripomočki}

Za ugotavljanje značilnosti učencev, ki so vrstniški mediatorji, in učencev, ki niso vrstniški mediatorji, smo sestavili vprašalnik, ki je vseboval pet demografskih vprašanj, eno vprašanje odprtega tipa, na katerega so odgovarjali samo vrstniški mediatorji (Zakaj so se odločili postati vrstniški mediatorji?), ter dva osebnostna vprašalnika. Vključili smo ocenjevalni lestvici: Indeks empatičnosti za otroke in mladostnike (Bryant, 1982; slovenska priredba Kroflič, 1998) in Lestvico samospoštovanja (Rosenberg, 1965), ki sta prevedeni v slovenščino.

\section{Indeks empatičnosti za otroke in mladostnike}

Indeks empatičnosti za otroke in mladostnike je ocenjevalna lestvica, ki obsega 22 trditev, prirejenih za otroke in mladostnike med 7. in 14 . letom. Avtorica lestvice, ki se v originalu imenuje Index of Empathy for Children and Adolescents, je Brenda K. Bryant. Trditve se nanašajo na empatičnost v vsakdanjih situacijah. Instrument naj bi meril empatičnost kot potezo in ne trenutno empatijo. Vsota odgovorov na indeksu predstavlja vsoto točk, ki kaže na stopnjo emocionalne empatičnosti posameznika. Čim višja je vsota, tem večja je empatičnost.

Bryantova je preverila psihometrične značilnosti ocenjevalne lestvice. Navaja naslednje Cronbachove koeficiente: $\alpha=.54$ za prvi razred, $\alpha=.68$ za četrti razred in $\alpha=.79$ za sedmi razred. Test-retest koeficienti zanesljivosti so pa naslednji: $\mathrm{r}=.74$ za otroke prvega razreda, $r=.8 \mathrm{I}$ za četrti razred in $\mathrm{r}=.83 \mathrm{za}$ sedmi razred. Rezultati na Indeksu empatičnosti praviloma rastejo s starostjo (Bryant, I928; v Kroflič, 1998). V nekaterih raziskavah, kjer so preverjali psihometrične karakteristike Indeksa empatičnosti, so ugotovili večdimenzionalnost lestvice. V raziskavi, ki so jo naredili De Wied in sodelavci (2007), so ugotovili, da lestvico sestavljata dva faktorja, ki so ju poimenovali Empathic Sadness in Attitude. Aluja, Del Barrio in Garcia (2004) so določili tri faktorje in jih poimenovali Feelings of Sadness, Understanding Feelings in Teartful Reaction. V slovenščino je instrument prevedla Breda Kroflič. Priredba Indeksa empatičnosti zajema 22 trditev. Primer trditve je: »Hudo mi je, če vidim osamljeno deklico, ki se nima s kom igrati.« Preverila je nekatere psihometrične karakteristike slovenske priredbe. Na vzorcu 177 otrok, starih ıo-ı let, je ugotovila, da je notranja konsistentnost $\alpha=.60$. Pri otrocih, starih $9-$ - 0 let, je bila zanesljivost po test-retest metodi $r=.77$. Uporaba lestvice je lahko poskusni instrument za nadaljne preučevanje in razvijanje instumentarija za merjenje empatičnosti pri otrocih in mladostnikih (Kroflič, 1998). V originalni lestvici Bryantove otroci do ı. leta odgovarjajo na trditve z DA ali NE, adolescenti pa z odločanjem na 9-stopenjski lestvici (Kroflič, 1998). Odločila 
sem se, da za namen te raziskave uporabim Likertovo 5-stopenjsko lestvico, to pa zato, da sem lahko ocenjevalno lestvico čim bolj približala mladostnikom, saj je 9-stopenjska lestvica preveč zapletena za to populacijo. Pri Likertovi lestvici je tako I pomenilo sploh ne drži zame, 2 - ne drži zame, 3 - delno drži zame, 4 - drži zame, 5 - popolnoma drži zame. Zanimala me je komponentna struktura vprašalnika, ki bi bila primerljiva $\mathrm{z}$ rešitvami drugih raziskovalcev (Aluja et al., 2004), zato sem iz sistema izločila 3 komponente. Vrednost preizkusa $\mathrm{KMO}=.78$ in Bartletovega preizkusa sferičnosti $\left(\mathrm{X}^{2}=\mathrm{I} 442,84, \mathrm{p}<.05\right)$ je pokazala, da so izpolnjene predpostavke za uporabo komponentne analize. Zanesljivost merjenja zanesljivosti celotne lestvice v tej raziskavi je Cronbach $\alpha=.77$. Izmerila sem tudi zanesljivost posameznih komponent: »Empatična čustva « (Cronbach $\alpha=.8 \mathrm{I}$ ), $\gg$ Razumevanje izražanja čustev« (Cronbach $\alpha=.56)$ in $\gg$ Empatične reakcije $\ll($ Cronbach $\alpha=.79)$.

\section{Lestvica samospoštovanja}

Samospoštovanje sem merila z Rosenbergovo lestvico samospoštovanja (1965), ki meri splošno samospoštovanje in zajema tako pozitivna kot negativna stališča, ki jih posameznik zavzema do samega sebe. Lestvica je enodimenzionalna, kar pomeni, da točkujemo lestvico kot celoto in zajema ıo postavk, od katerih je pet izraženih $\mathrm{v}$ pozitivni obliki, pet pa $\mathrm{v}$ negativni obliki. Udeleženci vrednotijo postavke na 4-stopenjski Likertovi lestvici od močno se ne strinjam (I) do močno se strinjam (4). Primer postavke je: »Sposoben/sposobna sem delati enako dobro kot večina drugih ljudi.« Visoko število točk pomeni visoko samospoštovanje. Cusatis in Shannon (1996; v Marčič, 2006) sta ugotovili, da je zanesljivost lestvice, izmerjena kot notranja skladnost, Cronbach $\alpha=.87$. Notranja konsistentnost v raziskavi Marčičeve (2006) je bila Cronbach $\alpha=.83$. V moji raziskavi se je pokazalo, da je lestvica enodimenzionalna, notranja konsistentnost lestvice je Cronbach $\alpha=.77$.

\section{Intervju za koordinatorje vrstniške mediacije na šoli}

Intervju za koordinatorje vrstniške mediacije sem sestavila na podlagi pregleda literature, ki je opisana $\mathrm{v}$ teoretičnem delu, in na podlagi posvetovanja z mentorico ter osebnega zanimanja za temo. Vsebuje 13 vprašanj odprtega tipa. Primer vprašanja je: »Kakšni so razlogi, da ste se na šoli odločili za vključitev vrstniške mediacije v preventivne vzgojne dejavnosti na vaši šoli? « 


\section{Postopek}

$\mathrm{V}$ novembru in decembru sem po dogovoru na šestih šolah v Mariboru in okolici aplicirala vprašalnik, ki je zajemal Lestvico samospoštovanja in Indeks empatičnosti za otroke in mladostnike. Vprašalnik za učence sem uporabila $\mathrm{v}$ razredih, kjer so bili vrstniški mediatorji, istočasno sem izvedla testiranje za učence, ki so vrstniški mediatorji, in za učence, ki niso vrstniški mediatorji. Tako so bili pogoji testiranja za vse učence enaki. Testiranja sem vodila sama, to pomeni, da sem podala navodila in razjasnjevala možna vprašanja. $\mathrm{Na}$ isti dan sem nato izvedla še intervju s koordinatorji vrstniške mediacije na šoli. S koordinatorji vrstniške mediacije na šoli sem intervju vodila večino časa direktivno, po vprašanjih, ki sem si jih vnaprej pripravila. Za razjasnitev kakšnega področja sem postavila podvprašanje ali postavila dodatno vprašanje (Mesec, 1998).

\section{Analiza rezultatov}

\section{Intervju}

Najprej sem zvočni posnetek intervjuja prepisala v pisno obliko. Nato sem izločila ali preoblikovala manj pomembno gradivo glede na raziskovalna vprašanja. Pridobljene podatke sem delno kvantitativno in delno kvalitativno obdelala. Kvantitativno sem obdelala recimo vprašanje: »Koliko časa že izvajate vrstniško mediacijo na šoli? « Podobno zasnovana vprašanja so bila tri. Ostala vprašanja sem obdelala na kvalitativen način s pomočjo Utemeljene teorije ( $\gg$ Grounded theory«), ki sta jo razvila Glaser in Strauss (1967; v Vogrinc, 2008). Pri kvalitativni obdelavi podatkov sem vključila še eno dodatno ocenjevalko, s katero sem povečala objektivnost rezultatov (Mesec, 1998).

\section{Vprašalnik za učence}

Podatke vprašalnika sem večinoma obdelala s pomočjo programa za statistično obdelavo podatkov SPSS. Eno vprašanje, ki je bilo kvalitativno in se je nanašalo na razloge, zakaj so učenci postali vrstniški mediatorji, sem obdelala kvalitativno ter s pomočjo dodatne ocenjevalke.

\section{Rezultati raziskave}

\section{Motivi za vrstniškega mediatorja}

$\mathrm{V}$ rezultatih bomo predstavili motive, zaradi katerih se učenci odločajo za vrstniškega mediatorja. Pomembno je, da vemo, kaj jih pritegne pri vrstniški mediaciji in kaj z vrstniško mediacijo pridobijo. 
Motive učencev za vključitev v program vrstniške mediacije smo preverjali z odprtim vprašanjem na vprašalniku: »Zakaj si se odločil/-a postati vrstniški mediator/-ka? « Pri vprašanju so lahko navedli več odgovorov. V Tabeli i lahko vidimo, da se učenci v največji meri odločijo postati vrstniški mediatorji, da bi pomagali drugim. Prav tako zato, da bi znali pomagati sebi, ko se bodo znašli v konfliktih. Veliko se jih je priključilo, ker jih je mediacija zanimala. Pritegnile so jih tudi same značilnosti mediacije, saj so jo zaznali kot konstruktivno metodo reševanja sporov in kot način za izboljšanje šolske klime. Za mediacijo so se odločili tudi zato, da bi osebnostno rastli, dobili uvid v občutja drugih, nova znanja o metodah sporazumevanja in da bi spoznali sebe. Na njihovo odločitev so vplivali tudi mladostniki, od katerih so slišali pozitivne informacije. Mediacija pa jim predstavlja tudi drugačen način druženja z vrstniki.

Tabela i: Motivi za vrstniškega mediatorja.

\begin{tabular}{|c|c|c|c|c|}
\hline Kategorije & Podkategorije & $\begin{array}{l}\text { Frekvence } \\
\text { odgovorov }\end{array}$ & $\begin{array}{c}\text { Skupna } \\
\text { frekvenca }\end{array}$ & Odstotek \\
\hline \multirow{2}{*}{ Nudenje pomoč } & Pomoč drugim & 43 & \multirow[b]{2}{*}{53} & \multirow[b]{2}{*}{51.5} \\
\hline & Samopomoč & Io & & \\
\hline \multirow{2}{*}{ Novost } & Nova izkušnja & 2 & \multirow[b]{2}{*}{ I4 } & \multirow[b]{2}{*}{13.6} \\
\hline & Zanimanje & 12 & & \\
\hline \multirow{4}{*}{$\begin{array}{l}\text { Konstruktivnost } \\
\text { mediacije }\end{array}$} & Izboljšanje šolske klime & 6 & \multirow{4}{*}{16} & \multirow{4}{*}{15.5} \\
\hline & $\begin{array}{l}\text { Miren način reševanja } \\
\text { sporov }\end{array}$ & 2 & & \\
\hline & Konstruktuktivna metoda & 4 & & \\
\hline & Vzpostavitev razumevanja & 4 & & \\
\hline \multirow{2}{*}{$\begin{array}{l}\text { Medvrstniški } \\
\text { vpliv }\end{array}$} & Druženje & 3 & \multirow[b]{2}{*}{9} & \multirow[b]{2}{*}{8.7} \\
\hline & $\begin{array}{l}\text { Mnenja vrstnikov } \\
\text { o mediaciji }\end{array}$ & 3 & & \\
\hline \multirow{3}{*}{ Osebnostna rast } & Uvid v občutja drugih & 2 & \multirow{3}{*}{ II } & \multirow{3}{*}{10.7} \\
\hline & Nova znanja & 3 & & \\
\hline & Spoznavanje sebe & 6 & & \\
\hline
\end{tabular}

\section{Značilnosti vrstniških mediatorjev}

Koordinatorke so povedale, da je pomemben kriterij za izbor prihodnjih vrstniških mediatorjev izpolnjevanje določenih norm. Pomembno je, da imajo vrstniški mediatorji določene osebnostne kvalitete, kot so komunikacijske sposobnosti, kar vključuje željo po komunikaciji, sposobnost poslušanja in družabnost; se prosocialno vedejo, kar vključuje empatičnost, prepoznavanje situacij, pripravljenost pomagati, prijaznost in samoiniciativnost; in so odgovorni za prepis zamujene snovi pri pouk, kadar zaradi mediacije ali izobraževanja zamudijo pouk. 
Tabela 2: Deskriptivne statistike lestvic.

\begin{tabular}{lcccc} 
& \multicolumn{4}{c}{ Opredelitev glede mediatorstva } \\
\cline { 2 - 5 } \multicolumn{1}{c}{ Spremenljivke } & Sem vrstniški mediator & Nisem vrstniški mediator \\
\hline Lestvica samospoštovanja & M & SD & M & SD \\
\hline Indeks empatičnosti & 20.42 & 3.97 & 20.65 & 4.49 \\
\hline Empatična čustva & 82.95 & 9.58 & 77.28 & 11.00 \\
\hline Razumevanje izražanja čustev & $21.8 \mathrm{I}$ & 2.82 & 20.02 & 3.92 \\
\hline Empatične reakcije & $37.7 \mathrm{I}$ & $4.6 \mathrm{I}$ & 36.06 & 5.66 \\
\hline
\end{tabular}

\section{Empatija}

Rezultati samoocenjevalnega osebnostnega vprašalnika Indeks empatičnosti za otroke in mladostnike so pokazali, da so vrstniški mediatorji dosegli višji rezultat na področju empatije, $\mathrm{M}=82.95, \mathrm{SD}=9.58$, primerjavi $\mathrm{z}$ učenci, ki niso vrstniški mediatorji, $\mathrm{M}=77.28, \mathrm{SD}=\mathrm{II}$.०. Izid t-testa je pokazal, da je razlika statistično pomembna, $\mathrm{t}=3.66, \mathrm{p}=.00, \mathrm{df}=\mathrm{II} 4,70$, $\mathrm{r}=.22$. Kaže se, da obstaja statistično pomembna razlika v doseženih točkah na Indeksu empatičnosti za otroke in mladostnike med vrstniškimi mediatorji in med učenci, ki niso vrstniški mediatorji, in sicer so vrstniški mediatorji bolj empatični od drugih učencev. Izid t-testa kaže razliko med povprečnim rezultatom na komponenti »Empatična čustva«, ki so ga dosegli vrstniški mediatorji in učenci, ki niso vrstniški mediatorji; razlika je statistično pomembna, $\mathrm{t}=3.96, \mathrm{p}=.00, \mathrm{r}=.32$. Prav tako izid t-testa na komponenti 2, »Razumevanje izražanja čustev«, kaže, da so vrstniški mediatorji dosegli višji povprečni rezultat v primerjavi z učenci, ki niso vrstniški mediatorji; razlika je statistično pomembna, $\mathrm{t}=2.09, \mathrm{p}=.04, \mathrm{r}=. \mathrm{I3}$. Podobno se kaže na tretji komponenti, »Empatične reakcije «, kjer so vrstniški mediatorji dosegli višji povprečni rezultat kot učenci, ki niso mediatorji, in je razlika ponovno statistično pomembna, $\mathrm{t}=2.64, \mathrm{p}=. \mathrm{OI}, \mathrm{r}=. \mathrm{I} 6$. Vrstniški mediatorji so tako na vseh treh komponentah empatije dosegli višji povprečni rezultat kot učenci, ki niso vrstniški mediatorji.

$\mathrm{Na}$ usposabljanju za vrstniškega mediatorja se učenci seznanijo tudi s temo o empatiji. Učijo se predvsem preko iger vlog in delavnic. Usposabljanje traja od šole do šole različno, na nekaterih šolah strnjeno 20 šolskih ur, na drugih celo šolsko leto. Ena kordinatorka je povedala, da je na njihovi šoli usposabljanje zelo intenzivno in lahko povzroči spremembe v značilnostih in obnašanju udeležencev.

\section{Samospoštovanje}

Obstaja tudi razlika med povprečnim rezultatom vrstniških mediatorjev in učencev, ki niso vrstniški mediatorji, na lestvici samospoštovanja. Izid 
t-testa je pokazal, da ta razlika ni statistično pomembna, $\mathrm{t}=-0.36, \mathrm{p}=.72$, $\mathrm{df}=262, \mathrm{r}=.02$.

Učinki uvedbe vrstniške mediacije v osnovne šole

Tabela 3: Učinki vrstniške mediacije.

\begin{tabular}{|c|c|c|c|}
\hline Kategorije & Podkategorije & $\begin{array}{l}\text { Frekvence } \\
\text { odgovorov }\end{array}$ & $\begin{array}{c}\text { Skupna } \\
\text { pogostost } \\
\text { odgovorov }\end{array}$ \\
\hline \multirow{2}{*}{$\begin{array}{l}\text { Sprememba v šolskem } \\
\text { okolju }\end{array}$} & Sprememba klime & 4 & \multirow[b]{2}{*}{5} \\
\hline & Prosocialno vedenje & $I$ & \\
\hline \multirow{2}{*}{ Sprememba pri učencih } & Uporaba mediacijskih veščin & 6 & \multirow{2}{*}{7} \\
\hline & Zmanjšanje medvrstniškega nasilja & $I$ & \\
\hline \multirow{2}{*}{$\begin{array}{l}\text { Sprememba } \\
\text { primediatorjih }\end{array}$} & Nova znanja mediatorjev & 2 & \multirow[b]{2}{*}{3} \\
\hline & Prenos znanj na vse učence & I & \\
\hline \multirow{2}{*}{$\begin{array}{l}\text { Sprememba } \\
\text { pri učiteljskem kadru }\end{array}$} & Uporaba mediacijih tehnik pri učiteljih & 2 & \multirow{2}{*}{5} \\
\hline & Več ukvarjanja s poučevanjem & 3 & \\
\hline \multirow{2}{*}{ Nedefiniran vpliv } & Ponekod ni sprememb & I & \multirow{2}{*}{2} \\
\hline & Pričakovanje dolgoročnih učinkov & I & \\
\hline
\end{tabular}

O učinkih uvedbe vrstniške mediacije v osnovnih šolah smo govorili s koordinatorkami vrstniške mediacije. Povedale so, da se pozitivni učinki kažejo na ravni šole in na osebnostni ravni. Koordinatorke so omenjale, da je uvedba mediacije vplivala na izboljšanje klime, povečanje prosocialnega vedenja in zmanjšanje medvrstniškega nasilja. Vidne so tudi spremembe pri vseh učencih šole, saj uporabljajo mediacijska znanja. Vrstniški mediatorji prenašajo znanje na ostale učence. Opažajo tudi, da se učitelji več ukvarjajo s poučevanjem kot z discipliniranjem. Koordinatorke so omenile tudi, da ponekod ni večjih sprememb, da se ni zmanjšalo število konfliktov, se pa ti konflikti rešujejo z manj posredovanja učiteljev. Koordinatorke na šolah pričakujejo dolgoročne učinke, in sicer večjo časovno generalizacijo priučenih veščin reševanja konfliktov. Treba je omeniti tudi, da šole nimajo sistematičnih postopkov za evalviranje učinkov mediacije, tako da zapisano temelji na subjektivnih opažanjih koordinatork.

\section{Zaključek}

Vrstniška mediacija se umešča med preventivne vzgojne dejavnosti (Metelko Lisec, 2008). Šole so jo vključile v svoj program zaradi izboljšanja šolske klime in komunikacije (Haft in Weiss, 1998; Rugelj, 200I). Vrstniško mediacijo so prepoznali tudi kot način spoprijemanja z vedenjskimi težavami učencev in kot način zmanjšanja nasilja na šoli (Haft in 
Weiss, 1998). Rezultati raziskave kažejo, da so vidni pozitivni učinki uvedbe vrstniške mediacije na osebnostni ravni pri učencih in na ravni šole. $\mathrm{Na}$ eni strani učenci vsakodnevno uporabljajo mediacijske veščine, prav tako pa mediacija vpliva na prosocialno vedenje in na manj medvrstniškega nasilja. Pomembni dejavniki, ki k temu lahko prispevajo, so medvrstniški vpliv, motivi učencev, ki želijo postati vrstniški mediatorji, osebnostne značilnosti mediatorjev in usposabljanje za mediatorje. Kaže se, da gre za posameznike, ki želijo pomagati sovrstnikom. Tudi Rugelj (20II) je ugotovila, da se učenci odločijo postati vrstniški mediatorji, da bi pomagali drugim. Zelo pomembna je tudi velika mera empatičnosti teh vrstnikov. Pomembno za mladostnike je tudi, da jim pri reševanju konfliktov pomaga vrstnik in ne odrasla oseba, saj ima mladostnik tako občutek, da ga mediator bolje razume (Baginsky, 2004; Cohen, 2012). Mediatorji se naučijo mediacijskih tehnik, ki jih lahko uporabljajo pri lastnih in tujih konfliktih. S spretnostmi, ki jih pridobijo, lahko odgovorno in uspešno odreagirajo v primeru medvrstniškega nasilja.

Uporabna vrednost raziskave je v njeni tematiki, saj je vrstniška mediacija dokaj nova preventivna dejavnost $\mathrm{v}$ slovenskem šolskem prostoru. Prav tako je področje osebnostnih lastnosti vrstniškega mediatorja s strani psihologov precej neraziskano. Glede na rezultate raziskave je vrstniška mediacija prinesla pozitivne učinke v slovenski šolski prostor, zelo ugodno je vplivala na spremembo šolske klime. V raziskavi smo dobili tudi informacijo, da mediacija vpliva na zmanjšanje medvrstniškega nasilja. Ker šole sistematično ne evalvirajo učinkov vrstniške mediacije, bi se lahko nadalje raziskalo povezanost med vrstniško mediacijo in medvrstniškim nasiljem.

\section{Literatura}

Aluja, A., Del Barrio, V., in Garcia, F.L. (2004) Bryant's empathy index for children and adolescents: psychometric properties in the spanish language, Psychological Reports 95, str. 257-262.

Baginsky, W. Peer mediation in the UK: a guide for schools. http://www. nspcc.org.uk/inform/publications/downloads/peermediationintheuk_wdf48055.pdf. (15.9. 2013).

Berčič, D. (2008) Vrstniška mediacija, Didakta 18/19/129, str. 13-18.

Berndt, T., in Keefe, K. (1995) Friend's influence on adolescents adjustment to school, Child Development 66, str. 1312-1329.

Bodine, R. J., Crawford, D. K., in Schrumpf, F. (2010) Vrstniška mediacija: reševanje konfliktov v šolah: vrstniški priročnik. Ljubljana: Zavod Rakmo. 
Bryant, B. (1982) An index of empathy for children and adolescents, Child Development 53 str. 413-425.

Cohen, R. (2012) Vrstniki razrě̌ujejo konflikte: vrstniška mediacija v šolah. Ljubljana: Zavod Rakmo.

Cuijpers, P., Koot, H. M., Van Lier, P. A. C., in Witvliet, M. (2009) Testing links between childhood positive peer relations and externalizing outcomes through a randomized controlled intervention study Journal of Consulting and Clinical Psychology 77(5), str. 905-915.

De Wied, M., Engels, R., Goudena, P., Maas, C., Matthys, W., Meeus, W., Van Goozen, S., in Vermande, M. (2007). Bryant's empathy index: A closer examination of its internal structure, European Journal of Psychological Assessment 23(2), str. 99-104.

Gilhooley, J., in Scheuch, N.S. (2000) Using peer mediation in clasrooms and schools, strategies for teachers, counselors, and administrators. Thousand Oaks, California: Corwin Press Inc.

Grebenc, V., Kodele, T., Kvaternik, I., in Rihter, L. (2010) Pogovarjajmo se: skupnostni pristop v šoli. Ljubljana: Fakulteta za socialno delo.

Haft S., W., in Weiss R. E. (1998) Peer mediation in schools: expectations and evaluations, Harvard Negotiation Law Review 3, str. 213-270.

Harris, R.D. (2005) Unlocking the learning potencial in peer Mediation: an evaluation of peer mediation modeling, and disputant learning, Conflict Resolution Quarterly 23(2), str. $14 \mathrm{I}-164$.

Haith M., Miller S. A., in Vasta, R. M. (1997) Dječja psihologija: moderna znanost. Jastrebarsko: Naklada Slap.

Iršič, M. (2010) Mediacija. Ljubljana: Rakmo.

Justin, J., in Zupančič, M. (1991) Otrok, pravila, vrednote: otrokov moralni in socialni razvoj. Radovljica: Didakta.

Klobasa, M. (2014) Vrstniška mediacija na osnounih šolah v Mariboru in okolici: značilnosti vrstniških mediatorjev in dosedanje izkušnje z mediacijo, Magistrsko delo, Maribor: Univerza v Mariboru, Filozofska fakulteta.

Košir, K. (2013) Socialni odnosi v šoli. Maribor: Subkulturni azil.

Kroflič, B. (1998) Učinki ustvarjalnega giba na nekatere vidike otrokovega intelektualnega, emocionalnega in socialnega razvoja. Doktorska disertacija, Ljubljana: Univerza v Ljubljani, Filozofska fakulteta.

Marčič, R. (2006a). Povezanost mladostnikove samopodobe in samospoštovanja z nekaterimi zdravju škodljivimi vedenji, Psihološka obzorja Is (4), str. $53-65$.

Mesec, B. (1998). Uvodv kvalitativno raziskovanje v socialnem delu. Ljubljana: Visoka šola za socialno delo. 
Metelko Lisec, T. (2008). Mediacija v vzgojno-izobraževalnih ustanovah nova kultura odnosov, Didakta, I8, str. 8-II.

Prgič, J. (2010) Šolska in vrstniška mediacija: vse, kar morate vedeti o mediaciji v šoli. Griže: Svetovalno-izobraževalni center MI.

Rogers, C., in Farson, R. (1987) Active listening. V: R.G. Newman, M.A. Danzinger in M. Cohen [ur.], Communicating in Business Today. D.C. Heath in Company. http://www.goget.org/pdf/Rogers_Farson.pdf. (10.12.2013).

Rosenberg, M. (1965) Rosenberg self-esteem scale. http://www.fetzer.org/sites/ default/files/images/stories/pdf/selfmeasures/self_measures_for_self-esteem_rosenberg_self-esteem.pdf. (25.10.2013).

Rugelj, D. (2011) Izkušnje z vrstniško mediacijo na izbranih osnovnih šola. Diplomsko delo. Ljubljana: Univerza v Ljubljani, Pedagoška fakulteta.

Vogrinc, J. (2008a) Pomen triangulacije za zagotavljanje kakovosti znanstvenih spoznanj kvalitativnega raziskovanja, Sodobna pedagogika 5, str. I08-I22.

DOI: https://www.doi.org/10.32320/1581-6044.30(3-4)169-182 